\title{
Antimicrobial and phytochemical screening of Icacina trichantha
}

\author{
Mohammed Hassan Shagal, Dimas Kubmarawa \\ Department of Chemistry, Modibbo Adama University of Technology, P.M.B., 2076, Yola, Nigeria
}

Email address:

shagal5787@yahoo.com(M. H. Shagal)

To cite this article:

Mohammed Hassan Shagal, Dimas Kubmarawa. Antimicrobial and Phytochemical Screening of Icacina Trichantha. American Journal of Biomedical and Life Sciences. Vol. 1, No. 2, 2013, pp. 37-40. doi: 10.11648/j.ajbls.20130102.11

\begin{abstract}
Ethanol and water extracts of Icacina trichantha leaves were screened for their phytochemicals and antimicrobial activity against Escherichia coli, Staphylococcus aureus, streptococcus spp, Candida albicans and Klebsiella pneumonia. The result indicated that alkaloids, tannins, saponins, and phenols were present in the plant part. Both the ethanol extract and the water extract were active against all the microorganisms. The ethanol extract was more active than the water extract. This attest to the fact that Icacina trichantha leaves contains bioactive compounds of potentially therapeutic significance and thus could be a promissory candidate for drug development and validates folkloric claim by the traditional healers.
\end{abstract}

Keyword: Icacina Trichantha, Ethanol, Extracts, Phytochemicals, Microorganisms, Drugs

\section{Introduction}

The primordial significance of plants in creation has continuously given limitless satisfaction to mankind. Without plants, there would probably be no other form of life on earth. Man has always been depending on plants for food, drink, shelter, clothing and medicine. This has started right from the origin of man [1]. Before the advent of western education, farming and trading were the main occupation of Africans. The fact that prior to the oil boom era in Nigeria, agriculture was the mainstay of the economy readily comes to mind apart from the nutritional essence of plant. However, the medicinal properties of plants have not been sufficiently harnessed. Folk medicine has existed from the earliest time and even ancient man knew that some plants extract could cure diseases and heal infirmities. The difficulty encountered with alternative medicine is that of a reliable documentation of known traditional herbal medicine since uses differ from one tribe, village or healer to another [2].

Indigenous medical practices have been the subject of much attention in the literature of various disciplines to date but the specificity, mode of action and clinical efficacy of most indigenous medicinal plants have not been established in a manner congruent with standards of modern pharmacognosy and pharmacology [3]. Nonetheless, this is not enough to discredit alternative medicine since the use of synthetic products stems from the modification of the structure and functions of some natural products.

The use of plants and their derived substances increases day by day for the discovery of new therapeutic agents owing to their versatile applications. From ancient time till now and tomorrow, the use of natural resources especially plants increases day by day for the discovery of new therapeutic agents. Natural products from some of these natural resources continue to be used in pharmaceutical preparations either as crude extracts, fractions, pure compounds or analogous compounds from highly active isolated compounds [4].

Plant-derived substances have recently become of great interest owing to their versatile applications. Medicinal plants are the richest bio-resource of drugs of traditional medicines, modern medicines, nutraceuticals, food supplements, folk medicines, pharmaceutical intermediates and chemical entities for synthetic drugs $[5,6]$. In spite of the recent domination of the synthetic chemistry as a method to discover and produce drugs, the potential of bioactive plants or their extracts to provide new and novel products for disease treatment and prevention is still enormous $[7,8,9]$. Several active compounds have been discovered from plants and used directly as patented drugs like taxol, artemisinin and maprouneacin[10,11,12]. Due to the multitargeting effect, inexpensive and safety of plant- 
based products compared to syntheticagents, there is a need for more and more searching and discovering of new drugs from plants.

Icacina trichantha is a scandent shrub up to $2 \mathrm{~m}$ with a very large tuber. Flower cream, ripe fruits red, about $21 / 2$ $\mathrm{cm}$ long with a sweet outer pulp, velvety: found in forest and jungle vegetation of southern Nigeria. Yorubas call it Gbegbe, Igbos call is Ibugo [13]. The plant is reported to become a weed of rice-padis in former Bendel state presently Edo and Delta states. The leaf is said to be used as a wrapper for castor oil seeds, but the purpose of wrapping them is not discussed. The thick yam-like root attains a large size. Yoruba says that it is edible alone. or dried and pounded to a white powder called gbe-wutu (Yoruba - Ijebudialet), which is used in soup, or added to a food known as Igalo made from food the roasted seeds of Citrulluslanatus (cucurbitaceae). Igbos treats it as a famine food eating the flour after prolonged maceration and repeated washing. The tuber is inflammable and when burning gives out so fierce a heat as to be unapproachable. Though the root is edible, a strong presence of alkaloid and benzophenone has been reported, the leaf contain a trace only. The Kernel appears to be not edible. Igbos considers the plant to be aphrodisiac, and they use it on soft tumors [13].

Therefore the aim of this study is to investigate the phytochemical and antimicrobial activities of ethanol and water extracts of Icacina trichantha leaves.

\section{Materials and Methods}

\subsection{Sampling and Sample Preparation}

Fresh sample of leaves of the plant were collected near University of Ibadan and identified in Forest Research Institute of Nigeria, Jericho, Ibadan. The plant part was washed with tap water and air-dried. The dried part was chopped into pieces, milled into fine powder by pounding manually with a clean and sterile pestle and mortar. The powdered sample was collected into sterile cellophane bags and labelled. The sample was kept in cool dry place till further use. The powdered sample was used for the extraction purposes.

\subsection{Extraction Process}

$20 \mathrm{~g}$ of the powdered plant sample was weighted in a beaker and percolated with $150 \mathrm{ml}$ of ethanol. The beaker was properly sealed with aluminum foil and left for 72 hours. The solution was then filtered using a funnel fitted in a filter paper and the extract obtained. The extract obtained was concentrated using rotary evaporator at $40^{\circ} \mathrm{C}$. The concentrated extract was stored in a universal bottle and refrigerated at $4^{0} \mathrm{C}$ prior to use [14].The above procedure was repeated with $20 \mathrm{~g}$ of fresh powdered sample with the use of $150 \mathrm{ml}$ of distilled water.

\subsection{Phytochemical Screening}

The subject of phytochemistry or plant chemistry is concerned with enormous variety of organic substance that are accumulated by plants and deals with chemical structures of these substance, their synthetic, turnover and metabolism, their natural distribution and biological functions [15].The preliminary phytochemical analysis of the extracts were carried out to determine the presence of tannins, flavonoids, saponins, alkaloids, phenols and glycosides as described by $[16,17]$.

\subsection{Test for Tannins}

The solution of the extract was shaken with small quantity of Ferric chloride. A blue-green precipitate was formed, which shows that tannin is present.

\subsection{Test for Flavonoids}

The solution of the extract was mixed with two drops of ammonia and does not give yellow-brown colour signifying the absence of flavonoids.

\subsection{Test for Saponins}

The solution of the extract was shaken with about $5 \mathrm{ml}$ of distilled water and then heated to boil. There was a formation of frothing, which indicated the presence of saponins.

\subsection{Test for Cardiac Glycosides}

The solution of the extract was dissolved in some glacial acetic acid containing one drop of $\mathrm{FeCl}_{3}$. The solution was underplayed with concentrated $\mathrm{H}_{2} \mathrm{SO}_{4}$. No formation of a brown ring at the inter-phase between the acetic acid layer and $\mathrm{H}_{2} \mathrm{SO}_{4}$ layer, which indicates the absence of cardiac glycosides.

\subsection{Test for Alkaloids}

The solution of the extract was warmed with $1 \% \mathrm{HCl}$ for two minutes. The mixture was filtered and few of Dragendorff's reagents were added. A reddish-brown colour and turbidity with the reagent indicated the presence of alkaloids.

\subsection{Test for Phenols}

The Solution of the extract was mixed with two drops of aqueous Ferric chloride. There was a formation of blueblack colouration, which indicates presence of phenol.

\subsection{Determination of Antimicrobial Activity}

Clinical isolates of Escherichia coli, Staphylococcus aureus, Streptococcus spp, Candida albicans and Klebsiella pneumonia were isolated in the microbiology laboratory of University of Ibadan. The bacterial and fungal cultures were maintained on nutrient agar medium and Sabourand dextrose agar medium respectively. 
Petri dishes were displayed on the laboratory bench; the molten media prepared were dispensed aseptically and then flamed and allowed to solidify. The media prepared were inoculated with the different test organisms and it is spread using sterile bent glass rod, and allowed to dry for 15 minutes. Thereafter, various holes were made on it, and then $0.5 \mathrm{ml}$ of the various extracts was pipette into various holes made on the media, then allowed the diffusion of the extracts for 15 minutes. The inoculated plates where incubated at $37^{\circ} \mathrm{C}$ for 24 hours. After 24 hours of incubation, diameters of zones of inhibition of various extract against the different (isolates) test organisms were measured. The results were taken by considering the zone of growth and inhibition of the organisms by the test fractions in millimeters [18].

\section{Results and Discussion}

The phytochemical analysis of the ethanol and water extracts of the Icacina trichantha leaves is shown in Table 1. Table 2 shows the antimicrobial efficacy of the ethanol and water extracts against the tested microorganisms.

Table 1: Phytochemical screening of ethanol and water extracts from leaves of Icacina trichantha

\begin{tabular}{lll}
$\begin{array}{l}\text { Phytochemical } \\
\text { components }\end{array}$ & Ethanol extract & Water extract \\
\hline Tannins & + & + \\
Flavonoids & - & - \\
Saponins & + & + \\
Cardiac glycosides & - & - \\
Alkaloids & + & + \\
Phenols & + & + \\
\hline$+=$ Present; $\quad-=$ Absent &
\end{tabular}

Table 2: Antimicrobial efficacy of ethanol and water extracts from the leaves of Icacina trichantha (zones of inhibition in $\mathrm{mm}$ )

\begin{tabular}{llll}
\hline Test organisms & $\begin{array}{c}\text { Extracts } \\
\text { Ethanol }\end{array}$ & Water & $\begin{array}{l}\text { Gentamycin } \\
\text { (control) }\end{array}$ \\
\hline Escherichia coli & 19 & 13 & 29 \\
Staphylococcus aureus & 15 & 09 & 31 \\
Streptococcus spp & 10 & 13 & 32 \\
Candida albicans & 07 & 06 & $\mathrm{R}$ \\
Klebsiella pneumonia & 11 & 15 & 22 \\
\hline
\end{tabular}

$\mathrm{R}=$ Resistance

The preliminary phytochemical tests carried out on the extracts revealed that Icacina trichantha contain tannins, saponins, alkaloids and phenols in the ethanol and water extracts. In both the extracts, flavonoids and glycoside were absent (Table 1). The phytochemicals present in both extracts of the tested plant part is an indication that the plant is of pharmacological importance.

Table 2 showed the antimicrobial activities of the ethanol and water extracts of the leaves of Icacina trichantha. Both extracts were active against all the tested microorganisms. The inhibition of growth of the tested microorganisms by the extracts has justified their use for the as traditional medicine.

The results obtained in this study (Table 2) indicate that the ethanol extract had preferable antimicrobial activity than the corresponding water extract, except for Streptococcus spp in which the water extract is more than the ethanol extract. The ability of the extracts to inhibit the growth of microorganisms shows a broad spectrum activity. The results also showed that Escherichia coli and Staphylococcus aureus were more susceptible to the ethanol extract than the water extract followed by Klebsiella pneumonia, Streptococcus spp and Candida albicans. This is similar to the report of [19].

These analyses suggest that the extracts of the indigenous plant contain active agents and could be promising candidates for drugs development and validate the tribal claims as a cure for some human ailments. This assertion is also confirmed as their extracts indicate a relatively moderate number of phytochemicals. Clinical and toxicity studies should be carried out on the extract to ascertain it safety when used.

\section{Competing Interest}

Authors have declared that no competing interests exist.

\section{Conclusion}

In conclusion, the ethanol extract was more active than the water extract. This attest to the fact that Icacina trichantha leaves contains bioactive compounds of potentially therapeutic significance and thus could be a promissory candidate for drug development and validates folkloric claim by the traditional healers.

\section{References}

[1] Akubue PI. Nigerian Medicinal Plants.Pharmacology and Toxicology. In: The State of Medicinal Plant Research in Nigeria (Edited by Abayomi, Sofowora) 1990; pp.53-54.

[2] Oliver-Bever B. Medicinal Plants in Tropical West Africa. Cambridge University Press 1986; pp.940

[3] Swain T. Plants in the Development of Modern Medicine Harvard University Press, Cambridge 1972; pp. 125 -129

[4] El-Sayed SA, Salih AB, Mohamed MS, Mortada ME and Eman AE.Phytochemical Studies and Evaluation of Antioxidant, Anticancer and Antimicrobial Properties of Conocarpus erectus L. Growing in Taif, Saudi Arabia. European Journal of Medicinal Plants 2012; 2(2): 93-112 
[5] Ncube NS, Afolayan AJ, Okoh AI. Assessment techniques of antimicrobialproperties of natural compounds of plant origin: current methods and future trends.Afri J Biotechnol 2008; 7: 1797-1806.

[6] NirmalaMJ, Samundeeswari A, Sankar PD. Natural plant resources in anticancertherapy-A review. Res Plant Biol 2011; $1: 1-14$

[7] Kviecinski MR, Felipe KB, Schoenfelder T, De Lemos LP, Rossi, MH, GonçalezE(2008). Study of the antitumor potential of Bidenspilosa(Asteraceae) used inBrazilian folk medicine. J Ethnopharm 2008; 117: 69-75.

[8] Newman DJ, Cragg GM, Snader KM (2003). Natural products as sources of new drugsover the period 1981-2002. J Nat Prod 2003; 66: 1022-1037.

[9] Verpoorte R.Pharmacognosy in the new millennium: lead finding andbiotechnology. J Pharm Pharmacol 2000; 52: 253-262.

[10] Goodman J, Walsh V. The Story of Taxol.Cambridge University Press: New York 2001; pp 123-143

[11] Klayman DL.Artemisia annua: from weed to respectable antimalarial plant. In: Kinghorn, A.D., Belandrin, M.F. (Eds.), Human Medicinal Agents fromPlants. American Chemical Society Series, Washington, DC 1993; pp.242-255

[12] Carney JR, Krenisky JM, Williamson RT, Luo J, Carlson TJ, Hsu VL, MoswaJL. Maprouneacin, a new daphnanediterpenoid with potent anti-hyperglycemicactivity from Maprouneaafricana. J Nat Prod 1999; 62, 345-347.
[13] Burkill, HM. Useful Plants of West Tropical Africa, $2^{\text {nd }}$, Vol. 1 Royal Botanical Garden, knew, 1985; pp. 88-91.

[14] Mann A, Yahaya Y, Banso A, John F. Phytochemical and antimicrobial activity of Terminaliaavicennioides extracts against some bacteria pathogens associated with patients suffering from complicated respiratory tract diseases. J Med Plants Res 2008; 2(5): 94-97.

[15] Harbone JB. Phytochemical Methods. Chapman and Hall, London 1991; pp. 84, 126, 199.

[16] Odebiyi A, Sofowora AE. Phytochemical screening of Nigerian Medicinal Plants Part III,Lloyida 1990; Pp. 234 246.

[17] Fadeyi MG, Adeoye AC, Olowokodejo JD. Epidermal and Phytochemical Studies with genus of Boerhavia(nyetanginaceae) Crude Drug Res 1989; 29: 178 184.

[18] Mackie R, McCartney C. Practical Medicinal Microbiology $3^{\text {rd }}$ edition, Vol. 2 Churchill Livingstone (publishers), London and New York 1989; Pp. 100- 106,121, 141, 163$167,303,432-491$

[19] Timothy O, Idu M. Preliminary phytochemical and in vitro antimicrobial properties of aqueous and methanol extracts of Icacina trichanthaOliv. Leaf.Int J Med ArmPlants2011; 1(3): 184-188. 